\title{
Effect of phosphorus, sulphur and phosphate solubilizing bacteria on yield, nutrient uptake and soil fertility after harvest of mustard
}

\section{N. J. JADAV, J. K. PARMAR, T. V. GANGWAL AND M. V. PATEL}

Received : 03.04.2016; Revised : 23.10.2016; Accepted : 18.11.2016

\section{MEMBERS OF RESEARCH FORUM:}

Corresponding author : J. K. PARMAR

Department of Agricultural

Chemistry and Soil Science, B. A.

College of Agriculture,

Anand Agricultural University

ANAND (GUJARAT) INDIA

Email: jkparmar.aau@gmail.com

Co-authors :

N. J. JADAV, T. V. GANGWAL

AND M. V. PATEL, C. P. College of Agriculture, S. D. Agricultural

University, SARDARKRUSHINAGAR (GUJARAT) INDIA

\section{Summary}

A field experiment was conducted to evaluate the effect of phosphorus, sulphur and phosphate solubilizing bacteria on growth and nutrient uptake by mustard [Brassica juncea (L.) Czern and Cosson.] grown in loamy sand soil. The experimental soil has $\mathrm{pH} 7.60$ and was deficient in available sulphur and nitrogen and medium in available phosphorus. The experiment was tested by Randomized Block Design with four replications. The treatments comprised of three levels each of phosphorus $\left(0,25,50 \mathrm{~kg} \mathrm{P}_{2} \mathrm{O}_{5} \mathrm{ha}^{-1}\right)$ and sulphur $\left(0,20,40 \mathrm{~kg} \mathrm{~S} \mathrm{ha}^{-1}\right)$ and two levels of phosphate solubilizing bacteria (PSB) inoculation (no inoculation and inoculation with Aspergillus niger strain-1). The results of the experiment revealed that each successive increase in level of phosphorus significantly increased the crop growth and uptake of nutrients. Different levels of sulphur significantly improved the growth, yield as well as uptake of nutrients by seeds and straw of mustard. Seed inoculation with PSB $\left(\mathrm{I}_{1}\right)$ significantly increased yield, uptake in seed and straw and availability of nutrients in soil. Combined effect of $50 \mathrm{~kg}$ $\mathrm{P}_{2} \mathrm{O}_{5} \mathrm{ha}^{-1}$ and $40 \mathrm{~kg} \mathrm{~S} \mathrm{ha}^{-1}$ with seed inoculation with PSB gave higher seed and straw yield as well as nutrient content in seed and straw which resulted in higher nutrient uptake by mustard grown in loamy sand of North Gujarat.

Key words : Phosphorus, Sulphur, PSB, Yield, Uptake, Fertility mustard

How to cite this article : Jadav, N.J., Parmar, J.K., Gangwal, T.V. and Patel, M.V. (2016). Effect of phosphorus, sulphur and phosphate solubilizing bacteria on yield, nutrient uptake and soil fertility after harvest of mustard. Asian J. Soil Sci., 11 (2) : 307-317 : DOI : 10.15740/HAS/AJSS/11.2/307-317. 